Brain, Beriavior and Evolution

Editor-in-Chief: R. Glenn Northcutt, La Jolla, Calif.

Reprint

Publisher: S. Karger AG, Basel

Printed in Switzerland
NASA-CR-204740

Original Paper

Brain Behav Evol 1995:46:362-370
Y i :

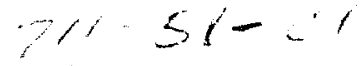

$91-51-21$

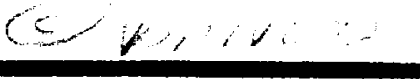

William M. Saidel ${ }^{a}$

Pamela J. Lanford ${ }^{b}$

Hong Y. Yanc

Arthur N. Popper ${ }^{b}$

Department of Biology,

Rutgers University, Camden, N.J.,

- Department of Zoology,

University of Maryland, College Park, Md.,

- Thomas H. Morgan School of Biological

Sciences, University of Kentucky,

Lexington, Ky.. USA

\section{Key Words}

Saccule

Hair cell structure

Cytochemistry

Immunocytochemistry

Ultrastructure

Goldfish

Phylogeny

Inner ear

\title{
Hair Cell Heterogeneity in the Goldfish Saccule
}

\begin{abstract}
A set of cytological studies performed in the utricle and saccule of Astronotus ocellatus (Teleostei, Percomorphi, Cichlidae) identified two basic types of hair cells and others with some intermediate characteristics. This paper reports on applying the same techniques to the saccule of Carassius auratus (Teleostei, Otophysi, Cyprinidae) and demonstrates similar types of hair cells to those found in Astronotus. Since Carassius and Astronotus are species of extreme taxonomic distance within the Euteleostei, two classes of mechanoreceptive hair cells are likely to represent the primitive condition for sensory receptors in the euteleost inner ear and perhaps in all bony fish ears.
\end{abstract}

\section{Introduction}

In the last few years, a set of studies examining both the cytology and physiology of hair cells in the ear of a teleost fish, Astronotus ocellatus, has revealed two distinct types [Saidel et al., 1990a, b; Yan et al., 1991; Chang et al.. 1992; Popper et al., 1993]. This discovery of different hair cell types in a fish inner ear is notable, because it contradicted an often-repeated assertion that the ears of teleosts possess only one structural type of vestibular hair cell, unlike the ears of amniotic vertebrates, which possess two types (types I and II) [e.g., Wersäll, 1956, 1960; Wersäll et al., 1965; Lowenstein, 1974; see Lewis et al., 1985]. The apparent lack of a type I hair cell in teleost ears suggested that the type I hair cell is a phylogenetically new receptor cell of amniotes.

Prior to these analyses of hair cells in Astronotus, most indications of hair cell variation in fishes were noted in SEM studies of ciliary bundle structure. For example, in the goldfish Carassius auratus [Platt, 1977] and other ver- tebrates [see review in Lewis et al., 1985], morphological differences in the absolute lengths of the kinocilium and stereovilli and relative differences in lengths of these two features of 'the teleost hair cell' were described. However, ciliary bundle variation does nor necessarily qualify as a characterization of different types of hair cells. Rather, this distinction may merely indicate different sensory or response dynamics [see Tumer et al. 1981], similar in style to the variation of chromatic sensitivities by different retinal cones [see Liebman, 1972].

In Astronotus, different types of physiological and cytological variations were determined for hair cell somata. Four characteristics that distinguish the two hair cell types were found: (i) positive or negative immunoreactivity to the calcium-binding protein S-100 [Saidel et al., 1990b]; (ii) degeneration or resistance to gentamicin-induced aminoglycoside toxicity [Yan et al., 1991]; (iii) definable and unique intracellular organelles [Wegner, 1982; Chang et al., 1992], and (iv) innervation by distinctive classes of afferent fibers [Saidel et al., 1990a]. The two hair cell types were
W.M. Saidel

Department of Biology

Ruigers University

Camden. NJ 08102 (USA)

0 1995 S. Karger AG, Basel 
predominantly located either in the striolar region of the utricle or external to the striola. The type of hair cell found in the striola was labeled a type-I like cell and the other, a type II cell [Chang et al., 1992].

These characteristics were first demonstrated for hair cells in the utricle of Astronotus. This analysis subsequently was extended to hair cells in the Astronotus saccule [Popper et al., 1993]. Although the aminoglycoside toxicity test was not used in that study, the other three techniques identified the different types of hair cells. The bulk of the receptor cells within the body of the saccular sensory epithelium (the type I-like cells) was different from that of the hair cells at the epithelial margin (the type II hair cells). These marginal cells also appear to be innervated by a class of eighth nerve afferent fibers distinct from the afferent fibers that innervate the type I-like cells [Presson et al., 1992].

All of the aforementioned studies focused on one fish species, Astronotus ocellatus, the oscar, which is a phylogenetically advanced teleost [Lauder and Liem, 1983]. However, the generality of these techniques as probes for identifying different hair cell populations in other fishes remains unknown.

In this report, we describe the results of applying the same cytological techniques to the saccule of Carassius auratus, the goldfish. Carassius belongs to the family Cyprinidae, superorder Otophysi, which is as phylogenetically distant from Astronotus (family Cichlidae, superorder Percomorphi) as is possible within the Euteleostei [Lauder and Liem, 1983; Nelson, 1984].

Much of the literature on teleost auditory neurophysiology and behavior has been derived from Carassius [e.g., Furukawa and Ishii, 1967; Jacobs and Tavolga, 1967; Fay, 1978, 1981]. Structural distinctions of hair cells in the saccule of this species would be of particular value to correlate with that literature. Two kinds of evidence already implied that hair cell populations in the goldfish saccule were nonhomogeneous. A patch-clamp study of hair cells from the goldfish saccule [Sugihara and Furukawa, 1989] suggested a correlation between different ion channels and ion currents with hair cells isolated from different saccular regions. Also, indirect evidence for different types of hair cells had been inferred from studies that focused on physiological responses from eighth nerve afferent fibers [see Fay, 1978, 1981, 1988; Sento and Furukawa, 1987].

The results presented here clearly localize different types of hair cells to specific regions of the saccular epithelium. In so doing, this paper extends the body of observations about hair cell differentiation in the goldfish saccule and in teleost fishes in general.

\section{Methods}

The details of each method have been described in prior publi a tions [Saidel et al., 1990a, b; Chang et al., 1992]. Animal procedu e: were approved by the UMCP Animal Care and Use Committee.

\section{S-100 Visualization}

Goldfish saccules were embedded in paraffin after fixation in paraformaldehyde in $0.1 M$ phosphate butfer. Saccules were embd ded in paraffin, serially cut at $4-6 \mu \mathrm{m}$, rehydrated to butfer, immer $\cdot$ in $5 \%$ goat serum in buffer for $1 \mathrm{~h}$ at $4^{\circ} \mathrm{C}$, rinsed in buffer, incubated with a primary polyclonal antibody diluted $1: 500$ overnight at $4 \cdot C$ (rabbit Anti-S-100, Incstar Corporation, no. 22520, lot no. 882102 and subsequently treated by the peroxidase-antiperoxidase (PAP) p.) cedure to visualize the S-100 antibody [Saidel et al., 1990b].

\section{Ultrastructure of Hair Cells}

The ultrastructure of saccular hair cells was examined usin slight variation in the technique used to define the organelle diff ences between hair cell types [Chang et al., 1992].

The saccular sensory epithelia from three $6 \mathrm{~cm}$ standard len specimens were obtained following deep anesthesia with MS-? ? opening of the otic chambers, and immersion in fixative $(2 \%$ pai iformaldehyde and $3 \%$ glutaraldehyde in $0.1 \mathrm{M}$ phosphate buffer, $1 \mathrm{H}$ 7.4) at room temperature. The ears were removed from the head a d immersed in fresh fixative. Additional fixative was injected into t e saccular pouch. Saccular otoliths were removed, and tissues remain. $d$ in fixative at room temperature for a minimum of $1 \mathrm{~h}$, then overnig it at $4{ }^{\circ} \mathrm{C}$. Sensory epithelia were post-fixed in $1 \% \mathrm{OsO}_{4}$ in $0.1 \mathrm{M}$ pho phate buffer, dehydrated and embedded in Embed 812 (EMS). Ti plastic was polymerized in a $60^{\circ} \mathrm{C}$ oven for $48 \mathrm{~h}$.

One saccule from each of the goldfish was sectioned. The epithe a of the first two saccules were cut perpendicular to the long axis (cro: :sectioned). The third saccule was sectioned parallel to the long axis (sagittally-sectioned). The first saccule was serially sectioned at $2 \mathrm{ui}$... and thin sections were sampled at $150-180 \mu \mathrm{m}$ intervals. The secol 1 saccule was not serially sectioned. Instead, thick and thin sections we e taken at 150-180 $\mu \mathrm{m}$ intervals. The third saccule was divided in two along the rostrocaudal axis. Each part was serially sectioned it $\mathrm{I}-2$, $\mathrm{m}$ along the long axis, and occasional thin sections were take:

Thin sections $(80-90 \mathrm{~nm})$ were stained with $5 \%$ methanolic ur. nyl acetate and $1 \%$ aqueous lead citrate. Sections from each of th = sampling intervals were examined and photographed in a Zeiss transmission electron microscope operated at $60 \mathrm{kV}$. Photograph : montages at $1,600 \times$ magnification of entire cross-sections at represe tative areas were made, and all hair cells in a montage were examine 1 for each of the identifying TEM characteristics [Chang et al., 1992 Each cell was categorized as a type-I like or type II hair cells or :" intermediate variety.

\section{Nerve Studies}

To distinguish between the types of nerve fibers that innervate th type I-like hair cells, as opposed to the type II hair cells, the ferri ferrocyanide nerve stain was used [see Quick and Waxman, 197: Saidel, 1988; Saidel et al., 1990a]. (This stain identifies electrogen: sites on a nerve membrane.)

Fish were deeply anesthetized in MS-222 and perfused with 0.7 $\mathrm{NaCl}$, followed by an initial fixative $(2.5 \%$ glutaraldehyde and $2 c$ paraformaldehyde in $0.1 \mathrm{~K}$ cacodylate buffer, $\mathrm{pH} 7.4$ ). The saccul: sensory epithelium was isolated with its innervating eighth nerve: 


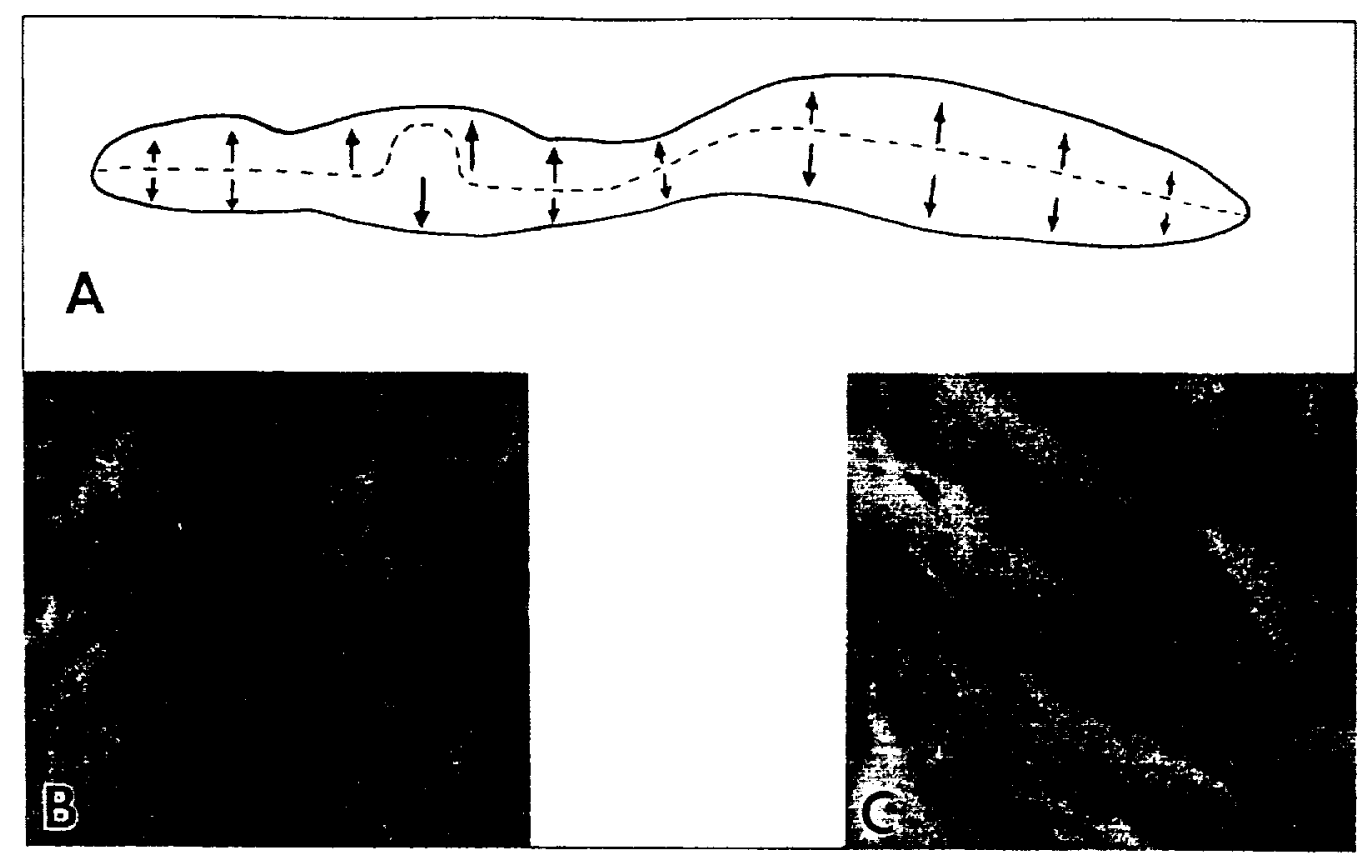

Fig. 1. Line drawing of the saccule (A) and scanning electron photomicrographs of hair cells in the rostral (B) and caudal (C) saccule in Carassius auratus. The saccular drawing illustrates its long and thin shape, with the pinch and horizontal twist that occurs about one-third to one-half the length from the rostral end. Arrows indicate the position of the single kinocilium within the ciliary bundle. Hair cells above the dashed line are polarized towards the dorsal pole of the fish; hair cells below it are polarized ventrally. Because of the epithelial twist, the shorter hair cells in the rostral saccule (B) are not collinear with the taller hair cells in the caudal saccule (C), B, C, $\times 1,680$, courtesy of C. Platt.

After fixation times of $2-3 \mathrm{~h}$, the epithelium was rinsed in buffer and postfixed in $1 \% \mathrm{OsO}_{4}$. After other rinses in buffer, tissues were immersed in $0.02-0.04 \mathrm{M} \mathrm{FeCl}_{3}$ for $2 \mathrm{~h}$. rinsed in distilled water, and immersed in $1 \% \mathrm{~K}_{4} \mathrm{Fe}(\mathrm{CN})_{6} \times 3 \mathrm{H}_{2} \mathrm{O}, \mathrm{pH} 2$, for 20 min with constant agitation. Tissues were embedded in an Epon-Araldite mixture and sectioned at $1-3 \mu \mathrm{m}$ with glass knives.

\section{Results}

The saccule of Carassius is relatively long and narrow (fig. 1; see Platt [1977]). A narrower region at the 'waist' divides the epithelium (macula) into rostral and caudal regions. Hair cells in the caudal region possess ciliary bundles that are distinctly taller than the ciliary bundles elsewhere on the epithelium (fig. lb, c) [Platt and Popper, 1984]. The cilia of these bundles extend to heights of $5-8$ $\mu \mathrm{m}$, instead of the $4-5 \mu \mathrm{m}$ found in the rostral saccular region. The ciliary bundles of hair cells in the most rostral of the rostral region are the shortest in height and progressively increase in size caudally.

Consistent differences between hair cells in the rostral and caudal regions of the saccular epithelium were found using each of the techniques. The cytoplasm of hair cells in the rostral region exhibited positive immunoreactivity to the S-100 antibody while the cytoplasm of caudal hair cells did not (fig. $2 \mathrm{~A}-\mathrm{C}$ ). On close examination, individual hair cells in the rostral region exhibited some variation in the intensity of the immunocytochemical reaction, although the reaction was present in all cells of this region. Immunoreactivity was also observed at the cuticular plate region of most hair cells (open arrow, fig. 2C).

Hair cell ultrastructure varied along the rostro-caudal axis of the saccular epithelium in a graded fashion (fig. 3) although hair cells at the extreme ends exhibited clear differentiation. Hair cells in the rostral $60-70 \%$ of the epithelium tended to possess larger diameter mitochondria, more subnuclear layering of the cisternae (which is probably a rough endoplasmic reticulum), and smaller synaptic bodies than hair cells in the remaining epithelium. These cells were innervated by relatively large diameter afferents whose preterminal endings were intraepithelially myelinated. The hair cells in the caudal region tended to possess smaller mitochondria, little or no subnuclear cisternae, and were most frequently innervated by small, unmyelinated 
Fig. 2. Transmitted light (A) and differential interference contrast $(\mathbf{B}, \mathbf{C})$ photomicrographs of hair cells in different saccular regions illustrating regional immunoreactivity to a polyclonal antibody against the calcium-binding protein $S-100$. In the rostrat saccule (A) and to the transitional region (B), hair cells exhibit strong cytoplasmic immunoreactivity; hair cells in the caudal saccule show negligible immunoreactivity to the same antibody (C). However, immunoreactivity ( $\mathrm{C}$, open arrow) is apparent at the cuticular plate of hair cells in all regions. Scale bars $=20 \mu \mathrm{m}(\mathbf{A})$ and $15 \mu \mathrm{m}(\mathbf{B}, \mathbf{C})$.
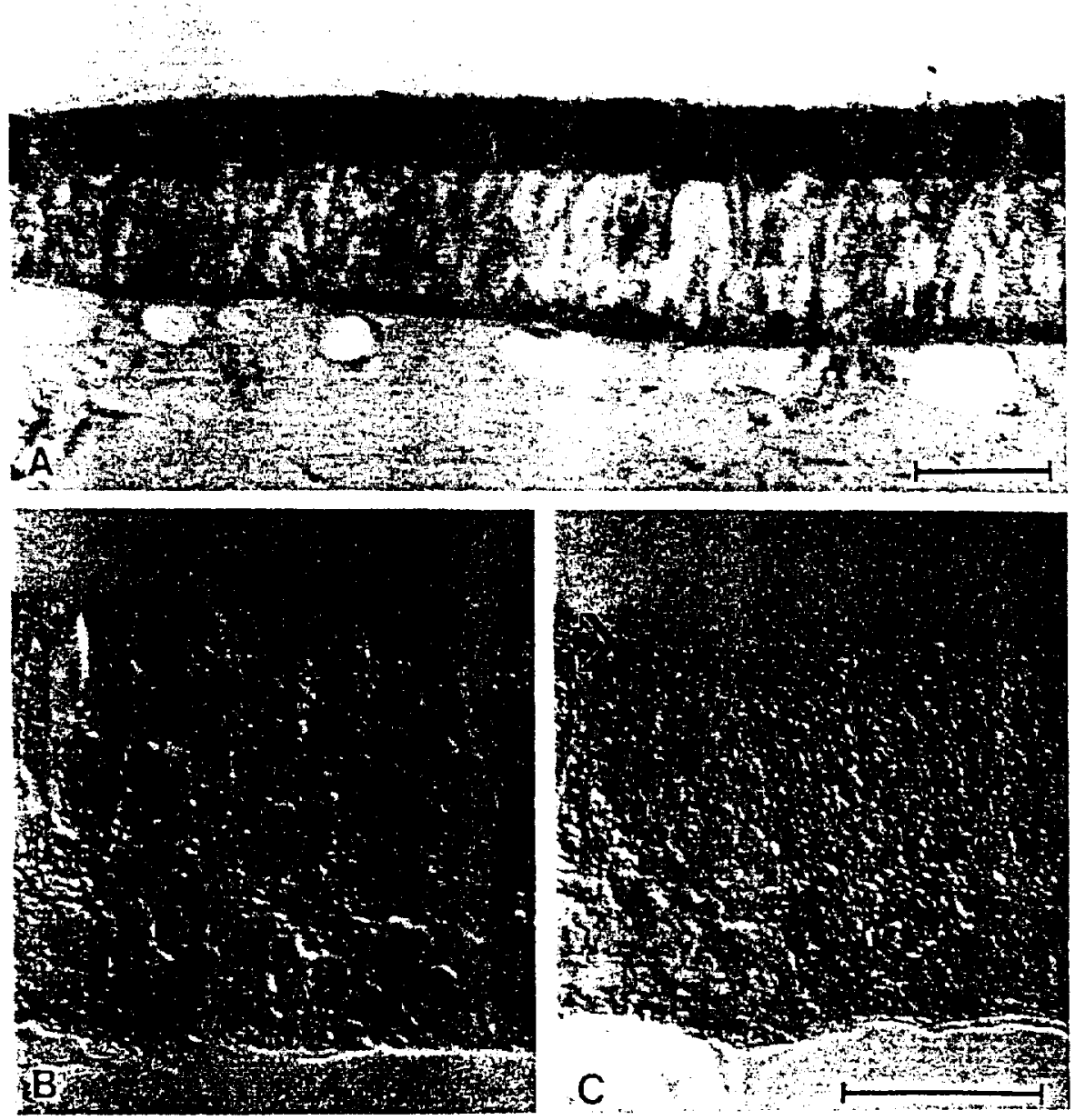

afferents. Along the long axis of the saccule, cells with a variety of intermediate forms between the morphological extremes were observed [P.J. Lanford and A.N. Popper, unpubl. observ.].

Finally, hair cells in the rostral saccule were innervated by a class of eighth nerve afferent fibers that was absent in the caudal region. The peripheral arbors of these afferents were distinguished by ferric-ferrocyanide staining of intraepithelial nerve branches. Such staining of postsynaptic membrane was widely seen throughout the rostral area (fig.4). No ferric-ferrocyanide staining of intraepithelial nerve processes was seen at the caudal end of the epithelium.

\section{Discussion}

The different and independent evaluations reported here demonstrate differences in the types of hair cells in the rostral and caudal regions of the saccular epithelium in Caras- sius auratus. These differences are similar to those exhibited by hair cells in the utricle and saccule of Astronotus. Using the terminology of Chang et al. [1992], each of these differences parallels the type I-like/type II dichotomy of hair cell structure first used to describe utricular hair cells in Astronotus [Saidel et al., 1990a, b; Yan et al., 1991; Chang et al., 1992].

\section{Comparing Cell Types Between Carassius and \\ Astronotus}

The differentiation between saccular hair cells of Carassius is also similar to the differentiation of hair cells in the saccule of Astronotus [Popper et al., 1993], except for distribution within the epithelium and cell size. The type I-like hair cells are located in the center of the saccular epithelium of Astronotus, while they are located in the rostral region of the goldfish epithelium. The type II hair cells are found in a few peripheral rows at the margin of the Astronotus saccule, whereas they dominate the caudal region of the goldfish 

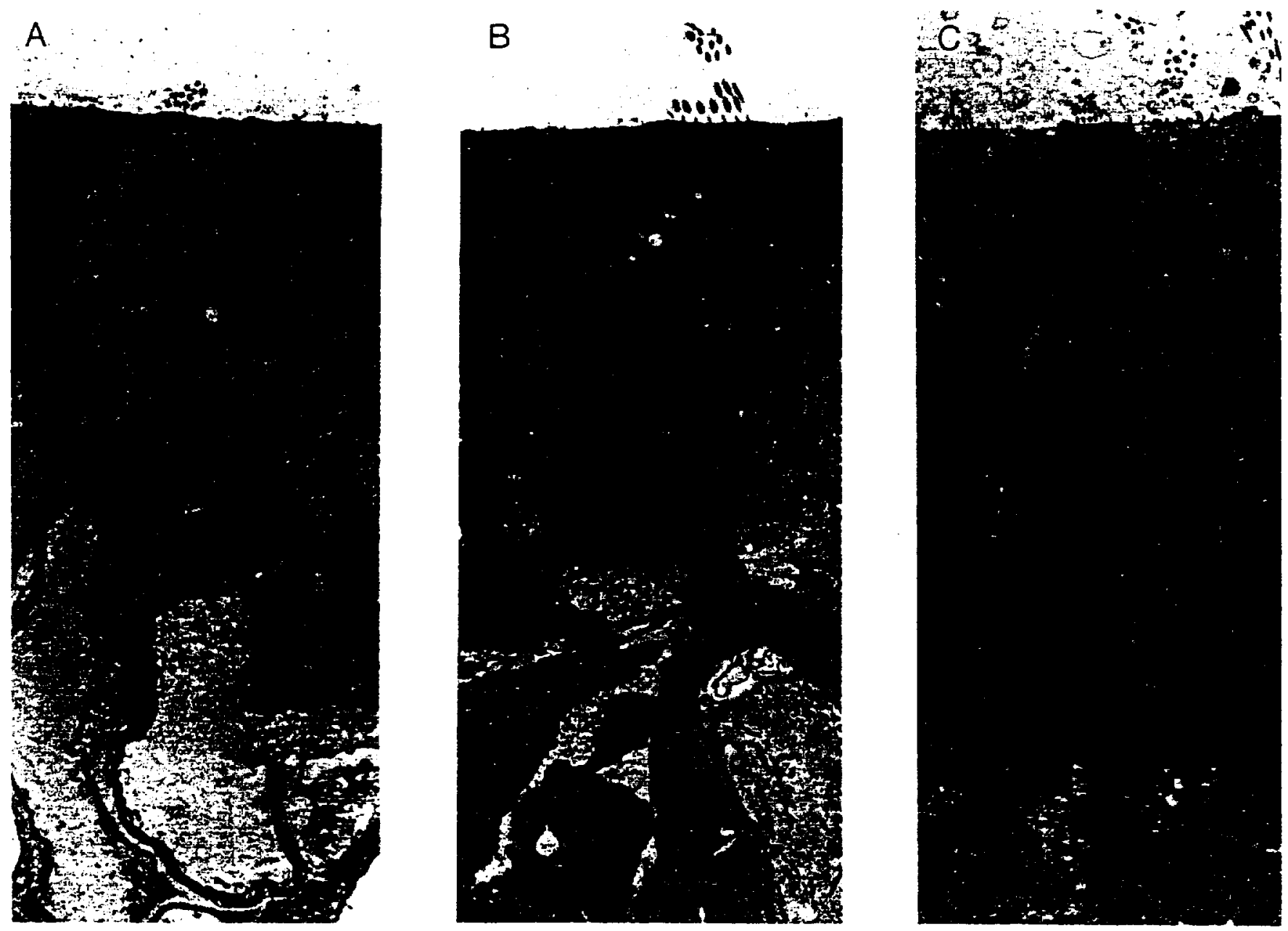

Fig. 3. Electron micrographs of hair cells from the rostral (A), central (B), and caudal (C) regions of a goldfish saccule showing rostrocaudal variation in the size and intracellular distribution of mitochondria, size and shape of synaptic bodies, the presence or absence of a subnuclear rough endoplasmic reticulum, and morphology of terminal afferents. at $\times 3,370$ magnification.

saccule (fig. 5). At the border between the rostral and caudal regions of the goldfish saccule, hair cells exhibit variations in some ultrastructural features. These variations have been studied in detail in the utricle, but not in the saccule of Astronotus. In the utricle, hair cells exhibiting similar variations are located between the type I-like hair cells in the striola and the type II hair cells in the extrastriolar region.

As noted above, the regional distributions of hair cell types in the saccules of Carassius and Astronotus differ. However, a common regional distribution of the type I-like and type II hair cells exists in the utricular and lagenar epithelia [W.M. Saidel and J.S.Y. Chang, unpubl. observ.].

Our fourth defining characteristic of the two hair cell types, differences in aminoglycoside ototoxicity [Yan et al.,
1991], was reported for the goldfish saccule recently by Platt and Yan [1993]. Gentamicin ototoxity destroyed hair cells in the rostral region while leaving hair cells in the caudal region intact. This observation is consistent with all the other evidence presented here categorizing the saccular hair cells of Carassius as two distinctive types, and it is also consistent with evidence for the susceptibility of the type Ilike cells for aminoglycoside ototoxicity in other otolithic epithelia [Yan et al., 1991].

\section{Is Hair Cell Size a Unique Characteristic?}

Interestingly, size, as measured along the long axis of a cell, provides a relative character for identifying the types of hair cells in different end organs. In Carassius, the 

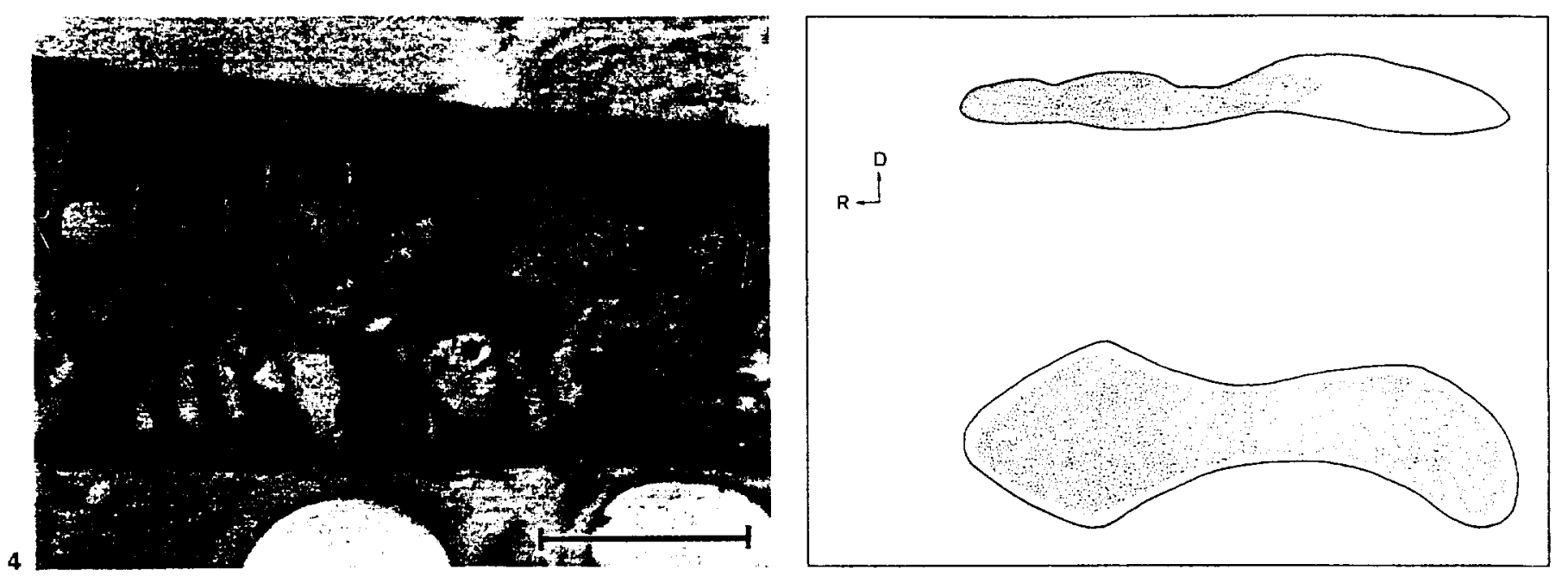

Fig. 4. Photomicrograph of terminal afferents in the rostral saccule after ferric-ferrocyanide staining (which identifies nodes of Ranvier and other axonal membrane with electrogenic properties). Arrowheads point to intraepithelial staining of postsynaptic afferents. Similar staining is not apparent in the caudal saccule. Scale bar $=20 \mu \mathrm{m}$.

Fig. 5. Line drawings of the saccule in Carassius (above) and Astronotus (below) showing the comparative distributions of type I-like hair cells (stippled areas) and type II hair cells (clear areas). R and D = rostral and dorsal, respectively.

immunoreactive type I-like hair cells (16-30 $\mu \mathrm{m}$; fig. 2, 3) are mostly shorter than the non-S-100 immunoreactive type II hair cells in the caudal region of the saccule $(26-32 \mu \mathrm{m})$. The immunoreactive hair cells increase in length along the rostrocaudal axis, although the longest immunoreactive hair cells remain shorter than the adjacent non-immunoreactive hair cells (fig. 2). That size relationship is paralleled in the saccule of Astronotus, where the immunoreactive type I-like hair cells are also shorter than the non-immunoreactive type II hair cells found at the saccular margins [Popper et al., 1993].

The size relationship of hair cells in the utricle of Astronotus is complicated by an additional feature. As in the saccule, the type I-like hair cells found in the striola are shorter than the adjacent type II juxtastriolar hair cells [Chang et al., 1992]. However, the type I-like striolar hair cells are longer than a population of non-immunoreactive type II hair cells of the utricular bowl [Chang et al., 1992]. Such short type II hair cells have not been described in the saccule. On size considerations, type II hair cells of the utricle eventually may be divided into subgroups.

\section{Phylogenetic Considerations}

Our observations in Carassius extend inner ear hair cell heterogeneity to a second superorder on the Euteleostei and strengthen the generality of the four criteria that have been used to distinguish between hair cell types in teleost ears.
Because of the phylogenetic distance between Astronotus and Carassius [Lauder and Liem, 1983; Nelson, 1984], we believe that many species within the Euteleostei will also possess at least these two classes of hair cells, and we suspect that hair cell heterogeneity may be a common occurrence throughout the entire Teleostei.

Previous electron microscopic studies in other species [an eel, Gymnothorax sp, Popper, 1979; the anabantids, Trichogaster, Popper and Hoxter, 1981; and Colisa labiosa, Wegner, 1982] did not report the distinct ultrastructural features that distinguish the type I-like hair cells from the type II [e.g., the very large perinuclear cistemae, the large mitochondria, and the distinctive shapes of synaptic bodies, Chang et al., 1992]. The early TEM studies of Carassius [e.g., Hama, 1969, 1980; Nakajima and Wang, 1974; Hama and Saito, 1977] lacked evidence for distinguishing type I-like hair cells from type $\Pi$ cells. Although we cannot be certain, non-systematic sampling in TEM studies may have led to the absence of a clear definition between types of hair cells in the species studied prior to our work.

However, hints do exist in the literature that hair cell heterogeneity may be widespread. Wegner [1982], in the one study that focused on hair cell structure and spatial location, identified regional ultrastructural differences among various hair cells in the lagena of the anabantid Colisa that are consistent with our definition of different types of hair cells. Indications of other types of ultrastruc- 
tural evidence for multiple hair cell types were found in a lamprey [Hoshino, 1975] and in elasmobranchs [Lowenstein et al., 1964; Corwin, 1977]. In the Japanese lamprey, Hoshino [1975] classified two types of hair cells based upon the presence or absence of a striated organelle that extends from the apical surface towards the basal end of a hair cell. Although these organelles do not resemble the perinuclear cisternae found in Carassius or Astronotus, their presence or absence suggests the ear in lampreys contains more than one type of hair cell.

Studies from the ear of the thornback ray [Lowenstein et al., 1964] and the macula neglecta of sharks of the genus Carcharhinus [Corwin, 1977] also contain data that are suggestive of heterogeneous hair cell types. Some hair cells possess a small structure that bears a resemblance to perinuclear cisternae while others do not. Neither study indicated whether specific types of hair cells are localized to a particular epithelial region, a conclusion consistent with our analyses in the goldfish saccule and the otolithic endorgans of Astronotus. Still, the evidence from species as divergent as lampreys, elasmobranchs, and other teleosts strongly supports an hypothesis that at least two different types of sensory hair cells are common for both bony and cartilaginous fishes.

The significance of this finding for the evolution of the ear and of hair cells, and the functional consequences of multiple hair cell types, is speculative. We note that mechanoreceptive hair cells serving as peripheral electroreceptors are considered an ancestral feature of vertebrates [Bullock et al., 1983; Bass, 1986], yet only two of the four groups of extant teleosts, the osteoglossomorpha and the euteleostei, possess electroreceptors. Because of their phylogenetic position, species of fish in these two groups must have evolved electroreception independently [Bullock et al., 1983]. It is reasonable to extend this reasoning to another type of mechanoreceptor. Theoretically, different groups within the teleostei might also have evolved multiple types of hair cells in different ear epithelia [see also Wever, 1974]. Equally plausible, heterogeneous hair cells of the teleostei and the heterogeneous hair cells of amniotic vertebrates may represent a convergent evolution.

Another perspective is suggested by the very recent report of Collazo et al. [1994]. He and his colleagues proved that hair cells in lateral line neuromasts possess a dual embryonic origin. They found that hair cells originate from both epidermal placodes and the neural crest. Given the extensive morphological similarities between hair cells of the lateral line and hair cells in the inner ear, this work raises the possibility that the two types of inner ear hair cells and their distinct innervations may reflect distinct em- bryological origins, perhaps with different roles in sensory processing.

\section{Functional Significance of Different Hair Cell Types}

Each of the examined otolithic epithelia of Carassius and Astronotus possessed the two types of hair cells, with some evidence for intermediate varieties. Functionally, in teleosts, no single otolithic organ has been uniquely identified with either an auditory or a vestibular sense. This situation is quite different from that of amniotic vertebrates. The vestibular epithelia of amniotes contain two hair cells, the classic type I and type II hair cells [Wersäll, 1956, 1960]. The auditory epithelia of amniotes possess inner and outer hair cells [see Lewis et al., 1985]. On strict morphological grounds alone, the vestibular hair cells of amniotes can be distinguished from the auditory hair cells.

No such distinction can clearly be made in the sensory epithelia of teleost ears. Using our four ćriteria, hair cells in the saccule (a presumptive auditory endorgan, e.g., von Frisch [1938a, b]) show little morphological distinction from hair cells in the utricle (a presumptive vestibular endorgan, Platt [1983]), suggesting that the peripheral organization of vestibular and auditory systems is not immediately comparable on functional grounds between teleosts and amniotes. Perhaps the clear distinction between the vestibular and auditory hair cells in amniotes was a consequence of the evolution of the basilar papillar and cochlea, structures not present in the ears of fishes.

It has been hypothesized that otolithic ear endorgans of fish may serve both the auditory and the vestibular sensory systems [e.g., Platt and Popper, 1981; Popper et al., 1982; Platt, 1983; Schellart and Popper, 1992]. Certainly, in some specialized cases, such as the herring-like fishes (Clupeidae) and marine catfish (Ariidae), the utricle does serve both auditory and vestibular functions [e.g., Blaxter et al., 1981; Popper and Tavolga, 1981], and in flatfish, the saccule controls posture [Schöne, 1964; Platt, 1973]. If multiple functions for teleost otolithic endorgans is the general case, then the acoustic and vestibular systems in fish may well be examples of unique sensory systems defined by the central nervous system, not by distinctive and identifiable peripheral endorgans nor by sensory receptor cells uniquely serving one sense. 


\section{Acknowledgements}

We thank Matthew Croce for graphic assistance and an anonymous reviewer for her/his perceptive comments. This work was supported in part by NIH grants NS-25876, DC-00140, DC-01729. ONR Grant N-00014-92-J-1114 and NASA grant NAG 2-787. Some of these results have been reported at the Annual Winter Meeting of the Association for Research in Otolaryngology [1987, 1990, 1993].

\section{References}

Bass. A.H. (1986) Electric organs revisited. In Electroreception (ed. by T.H. Bullock, and W. Heiligenberg), Wiley, New York. pp. 13-70.

Blaxter. J.H.S., E.J. Denton, and J.A.B. Gray (1981) Acoustico-lateralis systems in clupeid fishes. In Hearing and Sound Communication in Fishes (ed. by W.N. Tavolga, A.N. Popper, and R.R. Fay), Springer Verlag, New York. pp. 39-59.

Bullock. T.H., R.G. Northcutt, and D.A. Bodznick (1983) The phylogenetic distribution of electroreception: evidence for convergent evolution of a primitive vertebrate sensory modality. Brain Res. Rev., 6: 25-t6.

Chang, J.S.Y.. A.N. Popper, and W.M. Saidel (1992) Heterogeneity of sensory hair cells in a fish ear. J. Comp. Neurol., 324:621 -640.

Collazo, A.. S.E. Fraser. and P.M. Mabee (1994) A dual embryonic origin for vertebrate mechanoreceprors. Science, $264 t$ : $426-430$.

Corwin, J.T. (1977) Morphology of the macuta neglecti in sharks of the genus Carcharhinus. J. Morphol.. 152: $341-362$.

Fay, R.R. (1978) Coding of information in single auditory-nerve fibers of the goldfish. J. Acoust. Soc. Am. 63: 136-146.

Fay, R.R. (1981) Coding of acoustic information in the eighth nerve. In Hearing and Sound Communication in Fishes (ed. by W.N. Tavolga. A.N. Popper, and R.R. Fay), Springer Verlag, New York. pp. 189-219.

Fay, R.R. (1988) Peripheral adaptations for spatial hearing in tish. In Sensory Biology of Aquatic Animals (ed. by J. Arema. R.R. Fay, A.N. Popper, and W.N. Tavolga), Springer Verlag, New York, pp. $711-731$

Furukawa. T., and $Y$. [shii (1967) Neurophysiological studies on hearing in goldfish. J. Neurophysiol. 30 : $1377-1403$

Hama. K. (1969) A study on the fine structure of the saccular macula of the goldfish. Z. Zellforsch. 94: $155-171$.

Hama, K. (1980) Fine structure of the afferent synapse and gap junctions on the sensory hair cells in the saccular macula of the goldfish, a freezefructure study. J. Veurocysol., 9: 845-860.

Hama, K., and K. Saito (1977) Fine structure of the atferent synapse of the hair cells in the saccular macula of the goldtish, with special reference to the inastomosing cubules. J. Neurocytol., 6 . $361-373$
Hoshino. T. (1975) An electron microscopic study of the otolithic maculae of the lamprey (Entosephenus japonicus). Acta Otolaryngol. (Stockh.), 80: 43-53.

Jacobs, D.W., and W.N. Tavolga (1967) Acoustic intensity limens in the goldfish. Anim. Behay.. $15 \cdot 324-335$

Lauder, G.V.. and K.F. Liem (1983) The evolution and intertelationships of the actinopterygian fishes. Bull. Mus. Comp. Zool., 150: 95-197.

Lewis, E.R., E.L. Leverenz, and W.S. Bialek (1985) The Vertebrate Ear. CRC Press. Boca Raton.

Liebman. P.A. (1972) Microspectrophometry of photoreceptors. In Photochemistry of Vision (ed. by E.W. Abrahamson), Handbook of Sensory Physiology, Vol. VII, Part 1. Springer Verlag, Berlin, pp. $481-528$.

Lowenstein. O.. M.P. Osborne, and J. Wersäll (1964) Structure and innervation of the sensory epithelia of the labyrinth in the thornback ray (Raja clavata). Proc. Roy. Soc. Lond. B Biol. Sci., 160:1-12.

Lowenstein. O. (1974) Comparative morphology and physiology. In Vestibular System. Basic Vlechanisms (ed. by H.H. Komhuber), Handbook of Sensory Physiology, Vol. VI. Part !. Springer Verlag, Berlin, pp. $75-120$

Nakajima. Y.. and D.W. Wang (1974) Morphology of afferent and efferent synapses in hearing organ of the goidfish. J. Comp. Neurol., 156: $403-416$.

Nelson. J.S. (1984) Fishes of the World (2nd ed.) John Wiley and Sons, New York.

Platt. C. (1973) Central control of postural orientation in tlatfish. I. Postural change dependence on central neural changes. J. Exp. Biol., 59 $491-521$.

Platt. C. (1977) Hair cell distribution and orientation in goldfish otolith organs. J. Comp. Neurol., 172: 283-297.

Platt, C. (1983) The peripheral vestibular system of fishes. In Fish Neurobiology, Vol. 1, Brain Stem and Sense Organs (ed. by R.G. Northcutt. and R.E. Davis). University of Michigan Press. Ann Arbor, pp. 89-123.

Platt, C., and A.N. Popper (1981) Fine structure and function of the ear. In Hearing and Sound Communication in Fishes (ed. by W.N. Tavolga. A.N. Popper, and R.R. Fay). Springer Verlag, New York. pp. 3-38.
Platt. C.. and A.N. Popper (1984) Variations in lengths of ciliary bundles on hair cells alon the macula of the sacculus in two species 0 : teleost tishes. Scanning Electron Microsc., 4 $1915-1924$

Platt. C.. and H.Y. Yan (1993) Dramatic differ ences between fish species for gentamici pharmacotoxicity. Program and Abstracts 16th Annual Meeting. Assoc. Res. Otolaryn gol.: abstr. 562.p. 141.

Popper. A.N. (1979) The ultrastructure of the sac culus and lagena in a moray eel (Gymnothora sp.). J. Morphol., 161: $241-256$.

Popper, A.N. and B. Hoxter (1981) The fine struc ture of the sensory epithelia of the sacculu and lagena of a teleost fish. Hearing Res., 5 $245-263$.

Popper, A.N., C. Platt, and W.M. Saidel (1982 Acoustic function in the fish ear. Trends Neu rosci.. 5: 276-280.

Popper. A.N.. W.M. Saidel, and J.S. Chang (1993 Two types of sensory hair cells in the saccule 0 a fish. Hearing Res., 64: $211-216$.

Popper, A.N., and W.N. Tavolga (1981) Structur and function of the ear of the marine cattis Arius felis. J. Comp. Physiol. [A], 144:27-34

Presson, J.C., P.E. Edds, and A.N. Popper (1992 Central-peripheral and rostral-caudal orgas ization of the innervation of the saccule in cichlid tish. Brain Behav. Evol., 39: 196-20

Quick, D.C., and S.G. Waxman (1977) Ferric io ferrocyanide, and inorganic phosphate as cytc chemical reactants at peripheral nodes of Rar vier. J. Neurocytol., 6: 555-570.

Suidel. W.M. (1988) Trigger zone variacions in th vestibular system of fish. Neurosci. Lett., \& $161-166$

Saidel. W.M., and A.N. Popper (1983) Spati. organization in the saccule and lagena of a tel ost: hair cell pattem and innervation. J. Mo phol.. 177: 301-317.

Saidel. W.N. A.N. Popper, and J.S. Chang (1990 Spatial and morphological differentiation trigger zones in afferent fibers to the teleo utricle. J. Comp. Neurol.. 302: 629-642.

Saidel. W.M. J.P. Presson, and J. Chang (1990 Immunocytological reactivity to $S-100$ prote in a population of hair cells in the utricle an saccule of a fish. Hearing Res.. 47: 139- $1+6$ 
Schellart, N.A.M., and A.N. Popper (1992) Functional aspects of the evolution of the auditory system of actinopterygian fish. In Comparative Evolutionary Biology of Hearing (ed. by D.B. Webster, R.R. Fay, and A.N. Popper), Springer Verlag, New York, pp. 295-322.

Schöne, H. (1964) Über die Arbeitswe ise der Statolithenapparate bei Plattfischen. Biol. Jahres.. 4 : $135-156$.

Sento, S. and T. Furukawa (1987) Intra-axonal labeling of saccular afferents in the goldfish. Carassius auratus: correlations between morphological and physiological characteristics. J. Comp. Neurol., 258: 352-367.

Sugihara, I., and T. Furukawa (1989) Morphological and functional aspects of two different types of hair cells in the goldfish sacculus. J. Neurophysiol., 62: 1330-1343.
Tumer, R.G., A.A. Muraski, and D.W. Nielsen (1981) Cilium length: influence on neural tonotopic organization. Science, $213: 1519-1521$.

von Frisch, K. (1938a) The sense of hearing in fish Nature, $141: 8-11$.

von Frisch, K. (1938b) Über die Bedeutung des Sacculus und der Lagena für den Gehörsinn der Fische. Z. Vgl. Physiol.. 25: 703-747.

Wegner, N. (1982) A qualitative and quantitative study of a sensory epithelium in the inner ear of a fish (Colisa labiosa: Anabantidae). Acta Zool., 63: 133-146.

Wersäll. J. (1956) Studies on the structure and innervation of the sensory epithelium on the cristae ampulares in the guinea pig. Acta Otolaryngol. Suppl. (Stockh.), 126:1-85.
Wersäll, J. (1960) Vestibular receptor cells in fish and mammals. Acta Otolaryngol. Suppl. (Stockh.), 163:25-29.

Wersäll, J. A. Flock, and P.-G. Lundquist (1965) Structural basis for directional sensitivity in cochlear and vestibular sensory structures. Cold Spring Harb. Symp. Quant. Biol., 30. $115-132$.

Wever, E.G. (1974) The evolution of vertebrate hearing. In Auditory System (ed. by W.D. Keidel, and W.D. Neff), Handbook of Sensory Physiology, Vol. V/1, Springer Verlag, Berlin. pp. $423-454$

Yan, H.Y., W.M. Saidel, J.S. Chang, J.C. Presson, and A.N. Popper (1991) Sensory hair cells of fish ear: evidence of multiple types based on ototoxicity sensitivity. Proc. Roy, Soc. B Biol Sci., 245: 133-138. 